\title{
Metallography Evaluation of IN 718 after Applied Heat Treatment
}

Juraj Belan, Lenka Hurtalová, Alan Vaško, Eva Tillová

Faculty of Mechanical Engineering, Department of Materials Engineering, University of Žilina in Žilina, Univerzitná 8215/1, 01026 Žilina, Slovak Republic.

E-mail: juraj.belan@fstroj.uniza.sk, lenka.hurtalova@fstroj.uniza.sk, alan.vasko@fstroj.uniza.sk, eva.tillova@fstroj.uniza.sk

INCONEL alloy 718 is a high-strength; corrosion-resistant nickel chromium alloy used at $-253{ }^{\circ} \mathrm{C}$ to $705{ }^{\circ} \mathrm{C}$ for production of heat resistant parts of aero jet engine mostly. Mechanical properties of this alloy is strongly depended on microstructure and from presence of structural features such are gamma double prime $\left(\gamma^{\prime \prime}\right)$, gamma prime $\left(\gamma^{\prime}\right)$ and delta $(\delta)$ phases. Mentioned phases precipitate at various temperature ranges and $\mathrm{Nb}$ content as well. Article deals with applying of heat treatment at $800^{\circ} \mathrm{C}$ for 72 hours and its influence on structure changes. For microstructure evaluation a techniques of scanning electron microscopy (SEM) were used.

Keywords: Inconel alloy 718, Gamma double prime and Gamma prime precipitation, Heat treatment or Re-heating of alloy, Microstructure evaluation

\section{Acknowledgement}

This work has been supported by Scientific Grant Agency of Ministry of Education of Slovak Republic and Slovak Academy of Sciences, No1/0841/11 and project EU ITMS 26220220154.

\section{References}

[1] PAULONIS, D., F., OBLAK, J., M., DUVALL, D., S. (1969). Precipitation in nickel-base alloy 718, In: Trans. $A S M$, Vol. 62, No. 3, pp. 611-622.

[2] KIRMAN, I., WARRINGTON, D., H. (1970). The precipitation of Ni3Nb phases in a Ni-Fe-Cr-Nb alloy, In: Metallurgical Transactions, Vol. 1, No. 10, pp. 2667-2675.

[3] COZAR, R., PINEAU, A. (1973). Morphology of y' and y" precipitates and thermal stability of inconel 718 type alloys, In: Metallurgical Transactions, Vol. 4, No. 1, pp. 47-59.

[4] OBLAK, J., M., PAULONIS, D., F., DUVALL, D. S. (1974). Coherency strengthening in Ni base alloys hardened by DO22 $\gamma_{-}$precipitates, In: Metallurgical Transactions, Vol. 5, No. 1, pp. 143-153.

[5] SUNDARARAMAN, M., MUKHOPADHYAY, P., BANERJEE, S. (1992). Some aspects of the precipitation of metastable intermetallic phases in INCONEL 718, In: Metallurgical transactions. A, Vol. 23, No. 7, pp. 20152028.

[6] SLAMA, C., SERVANT, C., CIZERON, G. (1997). Aging of the Inconel 718 alloy between 500 and 750 ॰C, In: Journal of Materials Research, Vol. 12, No. 9, pp. 2298-2316.

[7] RADAVICH, J., F. (1989). The physical metallurgu of cast and wrought alloy 718. In: Superalloy 718 -Metallurgy and Applications (E., A. Loria (Ed.)), pp. 229-240. The Minerals, Metals \& Materials Society.

[8] EISELSTEIN, H., L. (1965). Metallurgy of a Columbium-Hardened Nickel-Chromium-Iron Alloy, ASTM Special Technical Publication No. 369, pp. 65-79.

[9] BARKER, J., F. (1965). Long Time Behavior of Turbine Materials, GE Report R65FPD51.

[10] DECKER, R., F. (1969). Strengthening Mechanisms in Nickel-Base Superalloys. In: Steel Strengthening Mechanisms Symposium, Zurich, Switzerland.

[11] BOESCH, W., J., CANADA, H., B. (1968). Precipitation Reactions and Stability of NisCb in Inconel7 18 Alloy. In: International Symposium on Structural Stability in Superalloys, pp. 579 - 596. Seven Springs, USA.

[12] BROOKS, J., W., BRIDGES, P. J. (1988). Metallurgical Stability of Inconel Alloy 7 18. In: Superalloys 1988 Symposium (Reichman, S., Duhl, D., N., Maurer, G., Antolovich, S., and Lund, C. (Ed.)), pp. $33-42$. The Metallurgical Society.

[13] ORADEI-BASILE, A., RADAVICH, J., F. (1991). A current t-t-t diagram for wrought alloy 7 18. In: Superalloys 718,625 and Various Derivatives (E., A. Loria (Ed.)), pp. 325-335. The Minerals, Metals \& Materials Society.

[14] BELAN, J. (2013). Study of advanced Ni - base ŽS6K alloy by quantitative metallography methods In: Manufacturing Technology, Vol. 13, No. 1, pp. 2-7. 
[15] HURTAlOVÁ, L., TILlOVÁ, E. (2013). Elimination of the negative effect of Fe-rich intermetallic phases in secondary (recycled) aluminium cast alloy In: Manufacturing Technology, Vol. 13, No. 1, pp. 44-50.

[16] VAŠKO, A. (2013). Influence of heat treatment on the microstructure of synthetic nodular cast iron. In: Manufacturing Technology, Vol. 13, No. 1, pp. 115-119.

Paper number: M201446

Copyright (C) 2014. Published by Manufacturing Technology. All rights reserved.

\section{Analysis of HVOF Coating on Molds Used for Refractory Fireclay Shapes}

Libor Beranek, Jiri Kyncl, Petr Mikes

Faculty of Mechanical Engineerign, Czech Technical University in Prague. Technicka 4, 16607, Prage 6. Czech Republic. E-mail: libor.beranek@fs.cvut.cz, jiri.kyncl@fs.cvut.cz,p.mikes@fs.cvut.cz

Molds used for pressing refractory fireclay shapes are exposed to very strong abrasive wear, which is given by the combination of applied pressure of more than $60 \mathrm{MPa}$ and processed materials like alumina $\left(\mathrm{Al}_{2} \mathrm{O}_{3}\right)$ and silica $\left(\mathrm{SiO}_{2}\right)$. Typical lifespan of molds is in several thousand cycles, our aim was to improve the lifespan 10 fold at minimum. To increase the lifespan of the critical parts of the molds, it was decided to use HVOF coating technology based on WC. This article evaluates the quality of the coating on the pins for pressing tools based on the technology used for deposition. An analysis was made on two sets of HVOF coated pins from different suppliers marked as a sample "A and B". Pins were analysed on tactile CMM with scanning system and samples from these pins were analysed on a multisensor CMM.

Keywords: HVOF Coating Thickness, Flatness, Mold Lifespan Increase

\section{References}

[1] NOUROUZI, S., AZIZPOUR, M.J., SALIMIJAZI, H.R., Parametric study of residual stresses in HVOF thermally sprayed WC-12Co Coatings, Materials and Manufacturing Processes, 2014, 29 (9), pp. 1117-1125.

[2] MYALSKA, H., MOSKAL, G., SZYMAŃSKI, K., Microstructure and properties of WC-Co coatings, modified by sub-microcrystalline carbides, obtained by different methods of high velocity spray processes, Surface and Coatings Technology, 2014.

[3] MASOUMI, H., SAFAVI, S.M., SALEHI, M., NAHVI, S.M., Effect of grinding on the residual stress and adhesion strength of HVOF thermally sprayed WC-10Co-4Cr Coating, Materials and Manufacturing Processes, 2014, pp. 1139-1151.

[4] OLADIJO, O.P., VENTER, A.M., CORNISH, L.A., Correlation between residual stress and abrasive wear of WC-17Co coatings, International Journal of Refractory Metals and Hard Materials, 2014, 44, pp. 68-76.

[5] VENTER, A.M., OLADIJO, O.P., LUZIN, V., CORNISH, L.A., SACKS, N., Performance characterization of metallic substrates coated by HVOF WC-Co, Thin Solid Films, 2013, 549, pp. 330-339.

[6] STEWART, D.A., SHIPWAY, P.H., McCARTNEY, D.G., Abrasive Wear Behaviour of Conventional and Nanocomposite HVOF Sprayed WC-Co coatings, Wear, 1999, 225-229, p 789-798

[7] GHABCHI, A., VARIS, T., TURUNEN, E., at al. Behavior of HVOF WC-10Co4Cr Coatings with Different Carbide Size in Fine and Coarse Particle Abrasion, J. Therm. Spray Technol., 2010, 19(1-2), p 368-377

[8] PAWLOWSKI, L.: The Science and Engineering of Thermal Spray Coatings. Second edition. John Wiley \& Sons, Ltd., 2008, 626 p. ISBN 978-0471-49049-4. 